\title{
Challenges of Transport Sector in India: A Dyadic Perspective*
}

\author{
Rajasekhara Mouly Potluri ${ }^{1}$, Satagopam Padma Tejaswi ${ }^{2}$ \\ Received: May 25, 2018 Revised: July 12, 2018 Accepted: July 30, 2018
}

\begin{abstract}
The objective of this research is to explore the diverse challenges faced by the customer as well transport providers through the selected modes of transportation of the second most populous country in the world - India. Two separate well-structured questionnaires administered to garner the opinions on different challenges. A random sample of 100 equally selected from the customers of 3 modes of transportation along with 30 transport providers. The collected data was analyzed in Microsoft Excel and R Studio platforms using Percentile Rank Tool and $\mathrm{R}$ Programming Language for Chi-square test respectively. Traffic congestion coupled with parking is the major problem in case of roadways while Safety and cleanliness in railways are the first amongst the problems to reckon with. High fares and lack of trained employees are the biggest challenges faced by aviation industry. The research is concentrated only in the states of Andhra Pradesh and Telangana in India with most widely used three modes of transportation viz., Road, Rail and Airways. This research paper is first of its kind which has collected the opinions of both customers as well transport providers on the problems faced. This research proffers information about the challenges faced by the customers which there will be an enormous possibility to review their strategies and plans.
\end{abstract}

Keywords: Transportation, Roadways, Railways, Airways, India.

JEL Classification Code: L91, L92, L93, N35.

\section{Introduction}

Transportation has undergone major changes over the past years from the days of animal drawn vehicles to the

* The paper was presented initially at 2018 International Conference on Business and Economics (ICBE2018) and the 14th International Conference of KODISA that was held in Seoul, South Korea, June 25-27, 2018. The paper has been recognized as one of Best Paper Awards at ICBE2018 conference. This paper is a substantially revised and expanded version of the paper presented at ICBE2018 conference. The authors have taken into account all the comments of Editors, Session Chairs and Reviewers in the revised manuscript. The authors greatly appreciate Editors, Session Chairs and Reviewers for their valuable comments, interest in and support of this research.

1 First Author. Associate Professor of Management/Marketing, School of Business \& Entrepreneurship, American University of Nigeria, Adamawa State, Nigeria. Email: raja.potluri@aun.edu.ng prmouly24@gmail.com

2 Corresponding Author. Post Graduate Student, Transportation Engineering, Department of Civil Engineering, National Institute of Technology Karnataka, Karnataka 575025, India; PhD Student, National Institute of Technology Warangal, Telangana 506004, India. Email: tejaswi.civil@gmail.com present day modernised mass transit systems. Excavations at Harappa and Mohenjo-Daro have revealed the existence of roads as early as 25 to 35 centuries B.C. During British rule in India, the development of roads and transport took place for the convenience of marketing and administration. The development of transportation is closely linked with the civilisation. With Industrialisation and urbanisation, necessity arose to develop various methods for transporting people and goods from one place to another. Industrial evolution stimulates the growth of cities due to the rapid settlement of population in the cities. As the workers live at a distant place from work place, providing cheap and efficient means of transport has become one of the essentials of the urban life. Efforts were made to replace animal power with mechanical energy. The public transport system in India begins in 1881 at Kolkata by Tramways Co. The early tramcars in Kolkata were drawn by horses. After a few years, steam locomotives were introduced to draw tramcars. Later, Petrol- driven buses replaced the tramcars in 1931 . The mechanical bus road transport started since 1920 in all big cities in India. Transportation contributes to the economic, industrial, social and cultural development of any country.

As the progress follows the lines of transportation, it is amongst the first issues to reckon with. Transportation is 
vital for the economic development of any region since every commodity produced needs transport at all stages from production to distribution. The adequacy of transportation system of a country indicates its economic and social development. In developing countries like India, with over 75 percent of the population of the country living in the villages, the development of urban centres do not indicate the overall development of the country. Overall economic progress can be achieved, only if the reasonable transport facilities are provided in rural areas as well. The traffic scenario in developing countries is different from that of the developed countries where the mixed traffic conditions exist in developing countries. India's transport is large and diverse.

Most Indian cities are still compact in their design with high population densities and mixed land use. The transport sector has not been able to keep pace with the rising demand and is providing to be a drag on the economy. With the improvement of transportation facilities in rural areas along with urban areas, the urge for the migration to urban areas decreases thus helps in balanced development of the country as a whole. The key element for sustainable mobility in cities is well developed public transportation and its quality is maintained by improving operational efficiency, harmonising tariffs and timetables, and improving accessibility and interchange facilities. To achieve a significant improvement in productivity and efficiency, it is imperative that future planning of India's transport network should aim at the development of multi modal transport (India Transport Report). This research study helps in identifying the various challenges faced by the transport providers and customers in transport sector of India.

\section{Literature Review and Hypotheses Development}

Transportation is defined as the movement of passengers and/or goods from one place to another. It is also defined as a means of conveyance or transfer from place to place. With the invention of wheel, the life of mankind changes tremendously. Transport systems of the world have undergone major challenges over the past 300 years from the days of animal drawn vehicles like Bullock-Carts, Horse driven vehicles, ferries to the present day computerised mass transit system. Roadways, being the largest mode of land transport, most of the research is related to urban transportation which includes planning, operation and management and only a limited research on other modes of transport. Pucher, Korattyswaroopam, and Ittyerah (2004) stated that previous studies on public transport services focused mainly on congestion, traffic problems, pollution levels, productivity, efficiency, demand etc. but there is a minimal research on passenger satisfaction on public transport services in Indian cities.

The increase in urban population results in the rapid growth of the cities which in turn results in the travel demand escalations. Most of the Indian roads are still compact in their design, resulting in the traffic congestion which in turn results in the long travel times. As a result of increased travel demand, there is an increase in usage of private vehicles in cities to which the available road space is not sufficient, resulted in the congestion. With the rise in the dependency of the private vehicles, there is a declining reliance on the public transportation (Agarwal, 2006). In order to retain and attract more passengers towards public transportation, it is necessary to maintain high service quality and fulfil the wide range need of different customers (Anable, 2005). According to Hoffman and Bateson (2006) customer satisfaction is the comparison of customer expectations to customer perceptions regarding the services provided by the transport providers. Zeithaml and Bitner (2006) has shown that customer expectations about service delivery serve as standards against which the performance of any organisation is judged. Customer satisfaction has also become a major contributor for enhancing the services provided by the company.

According to Manani, Nyaoga, Bosire, Ombati and Kongere (2013) measuring customer satisfaction provides an indication on how well an organisation is performing or providing a services. Therefore, customer satisfaction will be the measure of success to all the organisations including public sector as well. Miller (2013) in his research highlighted that public transportation is an efficient and environmentally friendly alternative to automobiles. Providing adequate and appropriate transportation services is a challenging task faced by all most all the cities in the world (Vijay, 2013). High quality public transport services not only makes the customer to continue using the public transport but also fulfil their demands so as to attract them. Oktiani (2009) in her thesis report says that frequency, comfort, travel time and safety are the four most important attributes that have strongest relationship with the overall satisfaction. Not only the road transportation, there is a considerable increase in the rail, air and water transport over the past years. There is a $9 \%$ increase in the rail passenger traffic (India transport report, 2014).

Indian Railways is the largest rail network in Asia. It is the premier transport organisation under one single management. Indian Railway Catering \& Tourism Corporation (2016) in their report on survey for cleanliness in various railway stations states that customers as well as vendors are not satisfied with the cleanliness maintained in 
the trains and stations. In the passenger satisfaction survey conducted by Dube (2012) has shown that the areas that should be given priority are the cleanliness, security and timely scheduling of trains. Fuel constitutes a major portion of overall airlines running cost that has put immense pressure on the bottom lines of any airlines and the airline industry (Chang \& Yang, 2008). Airline industry in India is very competitive and price conscious. Most of the Indians look for the service price instead of the brand (Magdum, 2015). Keeping in mind the views expressed by the different academicians and institutions, the researchers attempted to know the perceptions of transport customers through which transport providers can have an opportunity to once again review their entire marketing of their services so that there will be an enormous possibility to review the strategies and plans.

A well-coordinated transport system plays an important role in the sustained economic growth of the country. The basic modes of transport are by land, air and water. Land transport consists of roadways and railways. Water and air have developed waterways and airways respectively. Road transport is one of the most important transport in India. Road transport along with other modes of transport plays a key role in the movement of people and goods. It also contributes to the economic prosperity of the nation. Road transportation has the advantage over the other means of transportation because of its easy accessibility, flexibility of operation, door-to-door service and reliability. They carry almost 85 percent of the country's passenger traffic and more than 60 percent of its freight. The density of India's road network is at $1.70 \mathrm{~km}$ of roads per square kilometre of land. However, most roads in India are narrow and congested with poor surface quality. Railways and roadways are the dominant means of transport carrying more than $95 \%$ of the total traffic generated in the country. Railway has been the pioneer of modern mechanical transport. It has brought the greatest revolution in transport. It accelerated commercial and industrial development of various countries. Railways are ideally suited for long distance travel and movement of bulk commodities. It is the fourth largest network in the world. As of March 2017, the rail network comprises $121,407 \mathrm{~km}$ of track over a route of $67,368 \mathrm{~km}$ and 7,216 stations (Indian Railways, 2017). Urban rail transit also called metro is operated in 10 cities. As of November 2017, India has 425 kilometres of operational metro lines and 347 stations.

Transportation by water is cheapest but slowest among all the modes of transport. Waterways has two types transportation - Inland waterways and Ocean waterways. Waterways is possible between the ports on the sea routes or along the rivers, canals where inland water transport facilities are available. India has about $14,500 \mathrm{~km}$ of navigable waterways which comprise of rivers, canals, backwaters, creeks, etc. It is a fuel - efficient and environment - friendly mode. The advantages of waterways is that they are suitable for carrying bulk goods and heavy articles but not for public transportation due to its slow movement. India has a coast line length of $7617 \mathrm{KM}$ with 12 major airports and 187 minor airports.

Air transportation is the fastest among all the modes of transportation. It also provides more comfort apart from saving transport travel time. Air transport being the most modern and the quickest mode of transport has been gaining popularity. However, the exorbitant rates have made it the mode of travel of the rich or of the business community for whom time is more expensive than air travel. But the entry of private Airlines and their various schemes have reduced airfare drastically. Indian Airlines is the major domestic air carrier of the country. It operates to 57 domestic stations and 17 international stations in 14 countries. The development of airports is no longer solely under the public sector; instead private participation is allowed and encouraged. It does not require construction and maintenance of tracks for its operations but it is most expensive because of heavy investments in the construction of aero planes, air ports, control towers etc. Public transportation system and its impact on service delivery is driven by customers' perception and satisfaction. Vijay (2013) has strongly acknowledged that service quality is generally predicted as the sum of customer perceptions of the service experience. While Parasuraman, Zeithaml and Malhotra (2005), believed that the difference between service quality and satisfaction is perceived, service quality is a global judgment, related to the superiority of the service, whereas satisfaction is related to the specific transaction. Most of the research works is related to the attributes that influences the customer satisfaction like reliability, responsiveness and convenience (Cavana \& Corbett, 2007). Waiting time for long, failure to provide information of occasional delays and lack of good waiting environment are other factors are other causes of customer dissatisfaction (Bielen \& Demoulin, 2007).

The most important transport challenges are often related to urban areas and take place when transport systems, for a variety of reasons, cannot satisfy the numerous requirements of urban mobility. Urban productivity is highly dependent on the efficiency of its transport system to move labour, consumers and freight between multiple origins and destinations. The gaps of the service quality is a useful framework to understand service quality in an organisation. The main service quality gap is the customer gap. The customer gaps can be defined as the difference between the customer expectations and perceptions of the service. (Zeithaml \& Bitner, 2006). Customer expectations can be 
considered as standards, which customers place on the service experience, based on what they think should happen whereas Customer perceptions on the other hand can be thought of as the customer's valuation of the actual service experience (Zeithaml \& Bitner, 2006). In order to deliver quality services, a company must have a clear understanding of customer expectations. Customer expectations of services play a crucial role in their evaluation of the service quality.

H1: Most of the passengers used road transportation are satisfied with the services offered by the road transporter providers.

H2: Railway users are pleased with the services offered by the Indian railways.

H3: Indian civil aviation services are adeptly confident in delivering satisfied services to the public.

H4: Irrespective of mode of transportation, fuel related problems are major considerable impediment in providing most accurate service in India.

\section{Research Methodology}

This research study has employed two different wellstructured questionnaire for both transport providers and transport users to garner the opinions on the challenges faced by the selective modes of transportation in India viz., Road, Rail and Airways. To amass the necessary information, Andhra Pradesh and Telangana states of India are selected as the study location. Stratified random sampling method is used in this study. A random sample of 100 equally selected from the customers of three modes of transportation along with 30 transport providers. So a total of 390 respondents consisted of 300 customers and 90 transport providers were considered. The collected data was analysed in Microsoft Excel and R Studio platforms using Percentile Rank Tool and R Programming Language for Chi-square test respectively. Chi-square test is statistical tool used to assess the goodness of fit between observed value and theoretical value.

\section{Data Analysis and Discussion}

The data and the results obtained from 300 customers and 90 transport providers are tabulated hereunder. Table 1 provided information on the personal data of respondents ranging from sex, age and education. Majority of the respondents are male $(68.33 \%)$, while the female respondents are (31.67\%) in transport users and in transport providers also majority of the respondents are male $(76.67 \%)$ while female respondents are (23.33\%). Regarding the age, majority of the respondents are within the age group of $31-45$ years (36\%) followed by $15-30 y e a r s$, 46-60years and >60years with $33.66 \%, 23.33 \%$ and $7 \%$ respectively for transport users. Educational qualification of the respondents of transport users and providers, the details are given in the table hereunder.

Table 1. Demographic profile of the respondents

\begin{tabular}{|c|c|c|c|c|c|c|c|c|}
\hline \multirow{2}{*}{$\begin{array}{l}\text { S. } \\
\text { No }\end{array}$} & \multirow{2}{*}{ Variable } & \multirow{2}{*}{ Description } & \multicolumn{3}{|c|}{$\begin{array}{c}\text { Transport } \\
\text { users }\end{array}$} & \multicolumn{3}{|c|}{$\begin{array}{l}\text { Transport } \\
\text { Providers }\end{array}$} \\
\hline & & & $\begin{array}{l}\text { Road } \\
(100)\end{array}$ & $\begin{array}{l}\text { Rail } \\
(100)\end{array}$ & $\begin{array}{c}\text { Air } \\
(100)\end{array}$ & $\begin{array}{c}\text { Road } \\
(30)\end{array}$ & $\begin{array}{l}\text { Rail } \\
(30)\end{array}$ & $\begin{array}{l}\text { Air } \\
(30)\end{array}$ \\
\hline \multirow{2}{*}{1} & \multirow{2}{*}{ Sex } & Male & 61 & 65 & 79 & 23 & 21 & 25 \\
\hline & & Female & 39 & 35 & 21 & 7 & 9 & 5 \\
\hline \multirow{4}{*}{2} & \multirow{4}{*}{ Age } & 15 - 30 years & 30 & 35 & 36 & 4 & 4 & 4 \\
\hline & & 31 - 45 years & 39 & 34 & 35 & 9 & 7 & 7 \\
\hline & & 46 - 60 years & 23 & 23 & 24 & 11 & 14 & 14 \\
\hline & & $>60$ years & 8 & 8 & 5 & 6 & 5 & 5 \\
\hline \multirow{4}{*}{3} & \multirow{4}{*}{ Education } & Secondary & 33 & 25 & 10 & - & - & - \\
\hline & & Intermediate & 27 & 22 & 25 & - & - & - \\
\hline & & $\begin{array}{c}\text { Bachelor's } \\
\text { Degree }\end{array}$ & 23 & 29 & 35 & 19 & 18 & 13 \\
\hline & & PG Degree & 17 & 24 & 30 & 11 & 12 & 17 \\
\hline
\end{tabular}

\subsection{Challenges in the Transport Sector in India}

Transport facility is one of the important inputs for the overall economic development of the country. Transportation modes are an essential component of transport systems since they are the means by which the mobility is supported. Public transport faces severe problems in almost all countries of the developing world, although the situation varies from one country to another, and even from one city to another (Vasconcellos, 2001). The rapid growth of urban population results in the increase in the traffic on the roads which leads to the congestion. This can be due to illegal parking of vehicles on the road sides, hindrance to the motorised traffic by the NonMotorised vehicles, random movement of vehicles at the intersections etc. The scenario is completely different in case of railways and airways where they move on the dedicated lines.

The following Table $2 \& 3$ depicted the perceptions of both the transport users and providers on the challenges faced in using and introducing diverse modes of transportation viz., road, rail and airways. The results are shown in the percentages on five point Likert scale. 
Table 2. Perceptions of transport users on challenges

\begin{tabular}{|c|c|c|c|c|c|}
\hline Challenges & $\begin{array}{l}\text { Strongly } \\
\text { disagree \% }\end{array}$ & $\begin{array}{l}\text { Disagree } \\
\%\end{array}$ & $\begin{array}{l}\text { Neither agree } \\
\text { nor disagree } \%\end{array}$ & $\begin{array}{l}\text { Agree } \\
\%\end{array}$ & $\begin{array}{l}\text { Strongly } \\
\text { Agree \% }\end{array}$ \\
\hline \multicolumn{6}{|l|}{ ROADWAYS } \\
\hline There is frequent traffic congestion & - & 2 & 6 & 50 & 42 \\
\hline Availability for parking space is good & 26 & 33 & 9 & 21 & 11 \\
\hline $\begin{array}{l}\text { Difficulties for the movement of Non-Motorized traffic like } \\
\text { cycles in the traffic }\end{array}$ & 9 & 23 & 18 & 29 & 21 \\
\hline Pedestrians can cross the roads with ease and safely & 28 & 51 & 5 & 11 & 5 \\
\hline Public transport is not sufficient & 16 & 33 & 16 & 22 & 13 \\
\hline Waiting time at signalised intersection is high & 14 & 16 & 19 & 26 & 25 \\
\hline Responsiveness of the driver/ticket conductor is good & 13 & 20 & 17 & 23 & 27 \\
\hline Overall Satisfaction & 11 & 15 & 13 & 30 & 31 \\
\hline \multicolumn{6}{|l|}{ RAILWAYS } \\
\hline Adequate availability of dustbins & 26 & 38 & 8 & 13 & 15 \\
\hline Lack of cleanliness & 8 & 15 & 3 & 42 & 32 \\
\hline Condition of toilets and availability of water & 32 & 36 & 3 & 15 & 14 \\
\hline Lack of safety and security arrangements & 7 & 8 & 1 & 44 & 40 \\
\hline Late running of trains & 13 & 15 & 17 & 28 & 27 \\
\hline Quality of food is good & 34 & 28 & 12 & 15 & 11 \\
\hline Overall satisfaction & 20 & 27 & 15 & 20 & 18 \\
\hline \multicolumn{6}{|l|}{ AIRWAYS } \\
\hline Fares are very high & 11 & 13 & 7 & 33 & 36 \\
\hline Interactive quality of staff (cabin crew) is good & 23 & 25 & 15 & 23 & 14 \\
\hline Frequency of flights to different locations is good & 21 & 23 & 15 & 22 & 19 \\
\hline Time taken to deliver baggage & 8 & 10 & 4 & 40 & 38 \\
\hline Landing and take-off comfort & 11 & 13 & 13 & 30 & 33 \\
\hline On time performance & 7 & 15 & 12 & 31 & 35 \\
\hline Ambience & 5 & 8 & - & 44 & 43 \\
\hline Value for money & 18 & 26 & 15 & 22 & 19 \\
\hline Overall satisfaction & 8 & 11 & 9 & 40 & 32 \\
\hline
\end{tabular}

Table 3. Perceptions of transport providers on challenges

\begin{tabular}{|c|c|c|c|c|c|}
\hline Challenges & $\begin{array}{c}\text { Strongly } \\
\text { disagree \% }\end{array}$ & $\begin{array}{c}\text { Disagree } \\
\%\end{array}$ & $\begin{array}{c}\text { Neither agree } \\
\text { nor disagree \% }\end{array}$ & $\begin{array}{c}\text { Agree } \\
\%\end{array}$ & $\begin{array}{l}\text { Strongly } \\
\text { Agree \% }\end{array}$ \\
\hline \multicolumn{6}{|l|}{ ROADWAYS } \\
\hline High fuel costs & 4 & 4 & 2 & 9 & 11 \\
\hline Adequate trained drivers & 3 & 4 & 2 & 11 & 10 \\
\hline Lack of infrastructure & 3 & 3 & 4 & 10 & 10 \\
\hline Declining yields & 5 & 7 & 4 & 8 & 6 \\
\hline Proper toll fares & 3 & 10 & 6 & 6 & 5 \\
\hline Overall efficiency & 3 & 4 & 5 & 8 & 10 \\
\hline \multicolumn{6}{|l|}{ RAILWAYS } \\
\hline Fuel costs & 5 & 8 & 6 & 6 & 5 \\
\hline Responsiveness of staff & 6 & 8 & 6 & 5 & 5 \\
\hline Availability of quality and quantity of food to passengers & 4 & 6 & 5 & 7 & 8 \\
\hline Employee productivity & 7 & 8 & 4 & 6 & 5 \\
\hline Overall efficiency & 3 & 3 & 5 & 10 & 9 \\
\hline \multicolumn{6}{|l|}{ AIRWAYS } \\
\hline Lack of trained employees & 4 & 4 & 7 & 9 & 6 \\
\hline Fuel costs & 4 & 6 & 2 & 9 & 9 \\
\hline Investment & 3 & 5 & 3 & 10 & 9 \\
\hline Gaps in the infrastructure & 4 & 5 & 2 & 11 & 8 \\
\hline High airport fare & 4 & 3 & 3 & 9 & 11 \\
\hline Overall efficiency & 3 & 5 & 4 & 8 & 10 \\
\hline
\end{tabular}


Table 4. Results of Hypotheses

\begin{tabular}{|c|l|l|c|}
\hline S. No & \multicolumn{1}{|c|}{ Hypotheses } & \multicolumn{1}{|c|}{ Statistical Tool Used with Values } & Validity \\
\hline 1 & $\begin{array}{l}\text { Most of the passengers used road } \\
\text { transportation is satisfied with the services } \\
\text { offered by the road transporter providers. }\end{array}$ & $\begin{array}{l}\text { Percentile Rank for available Satisfactory factors : } \\
61 \text { percentile of passengers are having contentment with the } \\
\text { service offered by roadways. }\end{array}$ & valid \\
\hline 2 & $\begin{array}{l}\text { Railway users are pleased with the services } \\
\text { offered by the Indian railways. }\end{array}$ & $\begin{array}{l}\text { Percentile Rank for available Satisfactory factors : } \\
\text { Significantly, 62 percent of railway users are not contented with } \\
\text { the services. }\end{array}$ & Invalid \\
\hline 3 & $\begin{array}{l}\text { Indian civil aviation companies are adeptly } \\
\text { confident in delivering satisfied services to } \\
\text { the public. }\end{array}$ & $\begin{array}{l}\text { Percentile Rank for available Satisfactory factors: } \\
\text { Majority of the transporters (55\%), offering airway services to the } \\
\text { Indian public are fulfilled in delivering their responsibilities. }\end{array}$ & Valid \\
\hline 4 & $\begin{array}{l}\text { Irrespective of mode of transportation, fuel } \\
\text { related problems are major considerable } \\
\text { impediment in providing most accurate } \\
\text { service in India. }\end{array}$ & $\begin{array}{l}\text { Chi-squared test for given values: } \\
\text { Among Airway Transporters, there is a high P-Value for shortage } \\
\text { of trained employees (0.9735) and a trivial value for the problem } \\
\text { associated with the fuel (0.0019). } \\
\text { The same trend is observed in case of transporters offering } \\
\text { Roadways and Railways. }\end{array}$ & Invalid \\
\hline
\end{tabular}

\subsection{Testing of Hypothesis}

In the table 4 below, Hypothesis testing was carried out at $5 \%$ level of significance. If the $P$ value is less than 0.05 $(P<0.05)$, hypothesis is accepted. The first hypothesis affirmed that road transport users are satisfied (61\%) with the services offered by the providers whereas in case of second hypothesis, railway customers are not contented (62\%) with the services. Third hypothesis shows that Indian aviation companies are adeptly confident in delivering satisfied services to the public (55\%). Fourth hypothesis shows that fuel related problems are not major considerable impediment in providing most accurate service in India.

\section{Conclusion and Limitations of the Study}

This research paper is first of its kind which has collected the opinions of both customers as well transport providers on the problems faced in the transport sector in India. The study shows that traffic congestion is the major problem faced by transport users in India. Traffic congestion is a global as well as local problem. This results in the slower speeds and increased travel time. Other problems like parking, improper signals also leads to the traffic congestion. Illegal parking of the vehicles on the road sides decreases the capacity of the roads which in turn results in the traffic congestion. Followed by traffic congestion, the second major problem is movement of Non-Motorised traffic. Indian traffic is a heterogeneous traffic where the same roadway is shared by the motorised and non-motorised traffic. As the vehicles move with high speeds, movement to pedestrians and cyclists becomes difficult and sometimes leads to accidents also.
The same way, major challenges faced by the transport providers are increase in fuel prices and inadequate trained drivers. In the current scenario, there is a scarcity of the trained drivers and high fuel prices are likely to increase the transport cost. In case of railways, cleanliness and security is the major issue faced by the transport users followed by the availability of quality food. In majority of the trains, availability of water in the toilets and toilets cleanliness is not up to the mark particularly in case of second class travel. In most of the trains there is no proper security systems because of which theft cases registered are more, particularly, in general and second class compartments.

In case of airways, high fares followed by interactive quality of staff are the major challenges faced by the passengers. Customers are expecting better service quality from the cabin crew followed by food and ambience is the least bothered thing. Whereas for air transport providers, high operational costs and lack of trained employees are the problems. Operational costs include fuel costs, taxation and airport fare. Recently new airports are built in PPP mode with modern technology due to which huge investments are required. To recover this amount, airport holding company charges very high, thus directly results into high costs. It is important for the transport providers to know what customers expect so as to give quality service. The success or failure of any service organisation from every part of the globe completely depends on how effectively frontline staff delivers the required services based on the customization. It is therefore important for management to keep an eye on the frontline staff and their abilities to meet the customers' requirements by clearly understand the expectations of the diverse customers.

This research proffers invaluable information about the challenges faced by the customers based on which there will be an enormous possibility to review their strategies and 
plans. The limitations of the study is that the research is concentrated only in the states of Andhra Pradesh and Telangana in India.

\section{References}

Andreassen, T. W. (1995). (Dis)satisfaction with public service: The case of public transportation. Journal of Service Marketing, 9(5), 30-41.

Anable, J. (2005). Complacent car addicts or aspiring environmentalist: Identifying travel Segments using attitude theory. Transport Policy, 12(1), 65-78.

Anderson, W. S., Baggett. L. S., \& Widener. S. K. (2009). The impact of service operations failures on customer satisfaction: Evidence on how failures and their source affect what matters to customers. Manufacturing \& Service Operation Management, 11(1), 52-69.

Beirao, G., \& Sarsfield Cabral, J. A. (2007). Understanding attitudes towards public transport and private car: A qualitative study. Transport Policy, 14(6), 478-489.

Bielen, F., \& Demoulin, N. (2007). Waiting time influence on the satisfaction-loyalty relationship in services. Management Service Quality, 17(2), 174-193.

Cavana, R. Y., \& Corbett, L. M. (2007). Developing zones of tolerance for managing passenger rail service quality. International Journal of Quality Reliability Management, 24(1), 7-31.

Dube, K. (2012). Passenger satisfaction survey report and benchmarking of performance standards. Indian Railways Institute of Transport Management Lucknow. Government of India - Ministry of Railways, July.

Hoffman, K., \& Bateson, J. (2006). Services marketing: Concepts, strategies \& cases (3rd ed.). Mason, $\mathrm{OH}$ : Thomson /South-Western.

Kassian, A., \& Emmanuel, I. E. (2016). Critical assessment of public transportation system (PTS) and its implication on environmental economics through service delivery. Environmental Economics, 7(4), 3447.

Murambi, D. N. (2014). Service Quality and Customer Satisfaction in Public Transport Sector of Kenya: A Survey of Shuttle Travelers in Kitale Terminus. International Journal of Academic Research in Business and Social Sciences, 4(9), 402-412.

Mounika, V. (2014). Customer satisfaction level in public bus service in Tirupati, Andhra Pradesh (India). Asia Pacific Journal of Research, 1(10), 97-103.

Manani, T. O., Nyaoga, R. B., Bosire, R. M., Ombati, T. O., \& Kongere, T. O. (2013). Service quality and customer satisfaction at Kenya Airways Ltd. European Journal of Business and Management, 5(22), 170-179.

Miller, V. (2013). The leading force in advancing public transportation. Public Transportation is leading the Way in Green Vehicles. Press release [online]. Retrieved May 10, 2017 from http://www.apta.com/ mediacenter/pressreleases/2013/Pages/130422_Ear th-Day.aspx.

Maitry, S., \& Sinha, S. (2015). Analysing passenger perceptions of public transport: A case study of best - Mumbai. Proceedings of Eighth Urban Mobility India Conference \& Expo., India.

Oktiani, A. B. (2009). Customer satisfaction in public bus transport - A study of travellers' perception in Indonesia. Thesis for Master's in Karlstad University.

Pucher, J., Korattyswaroopam, N., \& Ittyerah, N. (2004). The crisis of public transport in India: overwhelming needs but limited resources. Journal of Public Transportation, 7(3), 95-113.

Pucher, J., Korattyswaroopam, N., Mittal, N., \& Ittyerah, N. (2005). Urban transport crisis in India. Transport Policy, 12(3), 185-198.

Pucher, J., Peng, Z., Mittal, N., Zhu, Y., \& Korattyswaroopam, N. (2007). Urban transport trends and policies in China and India: Impacts of rapid economic growth. Transport Reviews, 27(4), 379-410.

Parasuraman, A., Zeithaml, V., \& Malhotra, A. (2005). E-SQUAL: a multiple-item scale for assessing electronic service quality. Journal of Service Research, 7(3), 213-233.

Rabiul. I., Mohammed, S. C., Mohammad, S. S., \& Salauddin, A. (2014). Measuring customer's satisfaction on bus transportation. American Journal of Economics and Business Administration, 6(1), 3441.

Rajeswari, R. (2014). A Study on Customer Satisfaction in Airways - Coimbatore City. International Journal of Scientific and Research Publications, 4(12), 1-45.

Singh, S. (2016). Assessment of passenger satisfaction with public bus transport services: A case study of lucknow city (India). Studies in Business and Economics, 11(3), 107-128.

Survey of major railway stations for cleanliness ranking (2016). Indian Railway Catering \& Tourism Corporation.

Thomas Kolawole, O. J. O., Mireku, D. O., \& Dauda, S. (2014). Service Quality and Customer Satisfaction of Public Transport on Cape Coast-Accra Route, Ghana. IISTE, 4(18), 142-149.

Vijay, P. J. (2013). Measuring Perception on Service Quality Using SERVQUAL in Public Transportation. International Journal of Marketing Studies, 3(1), 1-14. 
Magdum, V. S. (2015). Report on Research and Analysis of Indian Aviation Industry. Thesis for Master's in Indian Institute of Management, Indore.

Wilson, A., \& Zeithaml, V. (2012). Services marketing: Integrating customer focus across the firm (2nd ed.). Maidenhead, Berkshire: McGraw-Hill Higher
Education.

Zeithaml, V., \& Bitner, M. (2006). Services marketing: Integrating customer focus across the firm (4th ed.). Boston: McGraw-Hill/Irwin. 